\title{
An estimation of total antimicrobial usage in humans and animals in Vietnam
}

\author{
Juan J. Carrique-Mas ${ }^{1,2^{*}}$ (D), Marc Choisy ${ }^{1,3,4}$, Nguyen Van Cuong ${ }^{1}$, Guy Thwaites ${ }^{1,2}$ and Stephen Baker ${ }^{1,5}$
}

\begin{abstract}
The accurate assessment of antimicrobial use (AMU) requires relating quantities of active ingredients (AAIs) with population denominators. These data can be used to prioritize potential sources of selective pressure for antimicrobial resistance and to establish reduction targets. Here, we estimated AMU in Vietnam (human population 93.4 M in 2015), and compared it with European Union (EU) data (population $511.5 \mathrm{M}$ in 2014). We extrapolated AMU data on each key animal species and humans from different published sources to calculate overall AMU (in tonnes) in Vietnam. We then compared these data with published statistics on AMU in the European Union (EU). A total of $3838 \mathrm{t}$ of antimicrobials were used in Vietnam, of which 2751 (71.7\%) corresponded to animal use, and the remainder (1086 t; $28.3 \%$ ) to human AMU. This equates to $261.7 \mathrm{mg}$ and $247.3 \mathrm{mg}$ per $\mathrm{kg}$ of human and animal biomass, compared with $122.0 \mathrm{mg}$ and $151.5 \mathrm{mg}$ in the EU. The greatest quantities of antimicrobials (in decreasing order) were used in pigs (41.7\% of total use), humans (28.3\%), aquaculture (21.9\%) and chickens (4.8\%). Combined AMU in other species accounted for $<1.5 \%$. These results are approximate and highlight the need to conduct targeted surveys to improve country-level estimates of AMU.
\end{abstract}

Keywords: Antimicrobial use, Surveillance, Human medicine, Veterinary medicine, Vietnam, European Union

\section{Main text}

Antimicrobial resistance (AMR) in bacterial pathogens is now firmly recognized as major global health problem [1]. AMR arises as a direct consequence of antimicrobial usage (AMU) in humans and animals and resistant organisms and AMR-encoding genes are capable of crossing species barriers [2]. Therefore, the emergence and transfer of AMR means that control solutions need to be conducted from a 'One Health' perspective [3]. However, if we are to reduce AMR we need accurate estimates of where the majority of AMU occurs. Sustained surveillance and monitoring of AMU are widely acknowledged as critical components of the fight against AMR and one of the strategic priorities of the AMR Global Action Plan (GAP) [4].

There is considerable uncertainty regarding AMU in different animal species and humans in most countries. This knowledge gap is due to the absence of reliable

\footnotetext{
* Correspondence: jcarrique-mas@oucru.org

${ }^{1}$ Oxford University Clinical Research Unit, Ho Chi Minh City, Vietnam

${ }^{2}$ Centre for Tropical Medicine and Global Health, Nuffield Department of Clinical Medicine, Oxford University Clinical Research Unit, 764 Vo Van Kiet, Ward 1, District 5, Ho Chi Minh City, Vietnam

Full list of author information is available at the end of the article
}

AMU data in humans and animals and ill-defined animal population denominators. Many higher income countries, such as those within the European Union (EU), regularly publish their data on AMU in humans and animals, and relate these values to denominator populations in terms of biomass [5]. Conversely, the majority of lowand middle-income countries (LMICs) do not regularly collect and report equivalent AMU statistics.

Recently, the World Organization for Animal Health (OIE) estimated that worldwide, on average $168.7 \mathrm{mg}$ of antimicrobial active ingredients (AAIs) were used to raise $1 \mathrm{~kg}$ of animal biomass [6]. Although the report does not include between-country- or species-specific data, it shows however considerable differences between different OIE regions. However, this report did not indicate which animal production sectors are responsible for the largest degree of AMU. Such data are essential for estimating where AMR is most likely to be generated and maintained and pivotal for policy makers to set reduction targets. Here, by integrating various data sources, we aimed to estimate AMU in humans and different animal populations in Vietnam. These data were

(c) The Author(s). 2020 Open Access This article is distributed under the terms of the Creative Commons Attribution 4.0 International License (http://creativecommons.org/licenses/by/4.0/), which permits unrestricted use, distribution, and reproduction in any medium, provided you give appropriate credit to the original author(s) and the source, provide a link to the Creative Commons license, and indicate if changes were made. The Creative Commons Public Domain Dedication waiver (http://creativecommons.org/publicdomain/zero/1.0/) applies to the data made available in this article, unless otherwise stated. 
compared against available human and animal AMU statistics from the EU.

Human biomass in Vietnam was calculated using 2015 population data stratified by age [7]. Adult ( $>18$ yearsold) body weight was taken from published Figs. $(58.4 \mathrm{~kg}$ males; $50.8 \mathrm{~kg}$ females) [8]. For non-adult age-gender strata, we assigned bodyweights to US populations [9], after adjusting for the difference in body mass between populations in the two countries. This was achieved by applying the correction factors of 0.642 and 0.651 , which represent, respectively, the ratios of weights of adult males and adult females in the two countries. The total biomass of terrestrial animals in Vietnam was calculated from official statistics [10] following the approach used by the OIE [6] that combined data on the number of slaughtered animals and standing populations. For aquaculture (farmed fish and shellfish), production data broken down by type of market (domestic, export) (2016) were used [11].

Data on human AMU in Vietnam were extracted from a multi-country survey in hospitals and the community [12]. The reported number of Defined Daily Doses (DDD) (per 1000) were converted to weight of antimicrobial active ingredient (AAI) using the four most common administered antimicrobials (ceftriaxone, ampicillin, azithromycin and levofloxacin). The daily consumption data was extrapolated for a whole year (365 days).

For pigs, chickens, and aquaculture (all aquatic species combined) data on AMU were obtained from quantitative published surveys [13-16]. Data on on AMU through consumption of commercial feed (i.e. antimicrobial growth promoters) were extrapolated from a survey of 1462 pig and chicken commercial feeds in Vietnam [17]. Antimicrobial consumption in aquaculture was extrapolated from a previous study [18], assuming that, on average, antimicrobial products have a $20 \%$ strength (weight of AAI related to total weight of product) based on the same study. For ruminants (bovines, buffaloes, sheep, goats) data on AMU in Japan (a high-income country in Asia) for 2010 were used [19]. For nonchicken poultry species (ducks, Muscovy ducks, geese and quails) the authors could not find any published data. AMU was, therefore, conservatively estimated as $50 \%$ of that reported in chickens, based on the authors' field experience. We excluded companion animals and equines since no AMU data are available. Best and worst-case AMU scenarios (i.e. lowest and highest AMU) were calculated for all species: for poultry species, upper and lower limits were calculated based on $\pm 25 \%$ of the final AMU estimate. For ruminants, the lower limit of AMU was taken from Japanese cattle AMU statistics [19]. The upper limit was set at 50\% higher than this estimate; for our summary estimations we used the intermediate value between these two limits. We compared the resulting AMU data with those published in the second ECDC/EFSA/EMA Joint Report on AMU (data for 2014), corresponding with AMU data in relation to the total biomass of terrestrial animal species in 28 EU countries [5] as well as with the Third World Organization for Animal Health (OIE) Report [6] (data for 2015).

Our estimates of human and animal biomass in Vietnam from the above calculations are 4153 and 11, 125 thousand tonnes, respectively (Table 2 in Appendix 1 and Table 1). Estimates of AMU showed that in 2015, a total of $3842 \mathrm{t}$ of antimicrobials were used in Vietnam, of which 2751 (71.7\%) was associated with animal use, and the remainder (1086 t; 28.3\%) corresponded to human AMU. The greatest quantities of antimicrobials (in decreasing order) were used in pigs (41.7\% of total use), humans (28.3\%), aquaculture (21.9\%) and chickens (4.8\%). Combined AMU in other species accounted for $<1.5 \%$ (Table 1 and Fig. 1). We estimate that, in total, $261.7 \mathrm{mg}$ (131.4-394.3 mg) of AAI were administered per $1 \mathrm{~kg}$ of human and $247.3 \mathrm{mg}(130.3-364.3 \mathrm{mg})$ per 1 $\mathrm{kg}$ of animal in Vietnam. The corresponding figures from the EU were $122.0 \mathrm{mg} / \mathrm{kg}$ and $151.1 \mathrm{mg} / \mathrm{kg}$ in humans and animals, respectively (Fig. 2).

Here, using a combination of available statistics alongside published AMU survey and extrapolation data, we estimated AMU related to biomass in humans and animal production in Vietnam. Our results suggest that in this country pig production and aquaculture should be the main target if the country aims to reduce its AMU footprint in animal production. AMU in humans in Vietnam (32.0 DDD per 1000 inhabitants per day) ranks higher than in most countries in the EU. These human data were generated using limited retail surveys [12]. However, EU countries such as Romania, Greece, France, Spain, and Ireland featured a higher magnitude of AMU (in terms of DDD related to population) than Vietnam. A recent report from Thailand, a LMIC country which is more comparable to Vietnam, estimated that in 2017 a total of 53.0 DDD per 1000 inhabitants per day were used in 2017 [20]. The Thai study used surveillance data on declared quantities of antimicrobials, which is a compulsory requirement for companies trading with antimicrobials in that country.

Whilst these are the first specific calculations for AMU in Vietnam, there is a considerable uncertainty around these estimates due to the lack of reliable data. For example, AMU data in humans, pigs, and aquaculture originate from single studies, all conducted prior to 2015. Furthermore, there are no data whatsoever on AMU in non-chicken poultry species and ruminants. The situation is likely to be even 
Table 1 Calculation of total annual AMU in each animal production type

\begin{tabular}{|c|c|c|c|c|c|c|c|c|c|}
\hline Category & Sub-category & $\begin{array}{l}\text { No. of } \\
\text { animals }\end{array}$ & $\begin{array}{l}\text { Type of } \\
\text { data }^{a}\end{array}$ & $\begin{array}{l}\text { Weight } \\
\text { unit }(\mathrm{kg})\end{array}$ & $\begin{array}{l}\text { Annual } \\
\text { bodymass } \\
(\mathrm{kg})\end{array}$ & $\begin{array}{l}\mathrm{AMU}^{\mathrm{b}}(\mathrm{mg} \\
\text { per kg) }\end{array}$ & $\begin{array}{l}\text { AGPs in commercial } \\
\text { feed ( } \mathrm{mg} \text { per } \mathrm{kg} \text { ) }\end{array}$ & $\begin{array}{l}\text { Total } \\
\text { AMU (mg } \\
\text { per kg) }\end{array}$ & $\begin{array}{l}\text { Total AMU } \\
\text { (tonnes) }\end{array}$ \\
\hline \multirow[t]{2}{*}{ Swine } & Breeding pigs & $\begin{array}{l}4,128 \\
032\end{array}$ & Census & 240 & $990,727,726$ & $46.1^{1}$ & $286.6^{2}$ & 332.7 & 329.6 \\
\hline & $\begin{array}{l}\text { Slaughter pigs (except } \\
\text { breeders) }\end{array}$ & $\begin{array}{l}48,567 \\
582\end{array}$ & Production & 78.6 & $\begin{array}{l}3,817,411 \\
914\end{array}$ & $46.1^{1}$ & $286.6^{2}$ & 332.7 & 1270.1 \\
\hline \multirow[t]{5}{*}{ Poultry } & Chickens & $\begin{array}{l}88,777 \\
000\end{array}$ & Production & 1.8 & $699,798,600$ & $187.7^{3,4}$ & $77.4^{2}$ & 265.1 & 185.5 \\
\hline & Ducks & $\begin{array}{l}101,931 \\
884\end{array}$ & Production & 2 & $203,863,767$ & $93.9^{5}$ & $38.7^{5}$ & 132.6 & 27.0 \\
\hline & Muscovies & $\begin{array}{l}17,652 \\
638\end{array}$ & Production & 3.2 & $56,488,440$ & $93.9^{5}$ & $38.7^{5}$ & 132.6 & 7.5 \\
\hline & Geese & 641,212 & Production & 3.2 & $2,051,877$ & $93.9^{5}$ & $38.7^{5}$ & 132.6 & 0.3 \\
\hline & Quails & $\begin{array}{l}13,526 \\
147\end{array}$ & Production & 0.13 & $1,758,399$ & $93.9^{5}$ & $38.7^{5}$ & 132.6 & 0.2 \\
\hline \multirow[t]{2}{*}{ Bovine } & Breeding bovines & $\begin{array}{l}3,472 \\
891\end{array}$ & Census & 325 & $\begin{array}{l}1,128,330 \\
008\end{array}$ & $52.4^{6}$ & 0.0 & 52.4 & 59.1 \\
\hline & $\begin{array}{l}\text { Slaughter bovines } \\
\text { (except breeding } \\
\text { animals) }\end{array}$ & $\begin{array}{l}1,220 \\
131\end{array}$ & Production & 200 & $244,026,240$ & $52.4^{6}$ & 0.0 & 52.4 & 12.8 \\
\hline \multirow[t]{2}{*}{ Buffalo } & Breeding buffaloes & 378,549 & Population & 500 & $189,274,500$ & $52.4^{6}$ & 0.0 & 52.4 & 9.9 \\
\hline & Slaughter buffaloes & 297,216 & Production & 300 & $89,164,711$ & $52.4^{6}$ & 0.0 & 52.4 & 4.7 \\
\hline \multirow[t]{2}{*}{ Sheep } & Breeding animals (est.) & 26,901 & Census & 75 & $2,017,556$ & $52.4^{6}$ & 0.0 & 52.4 & 0.1 \\
\hline & $\begin{array}{l}\text { Number slaughtered } \\
\text { (except breeders) }\end{array}$ & 64,368 & Production & 75 & $4,827,600$ & $52.4^{6}$ & 0.0 & 52.4 & 0.3 \\
\hline \multirow[t]{2}{*}{ Goats } & Breeding animals (est.) & 444,411 & Census & 75 & $33,330,833$ & $52.4^{6}$ & 0.0 & 52.4 & 1.7 \\
\hline & $\begin{array}{l}\text { Number slaughtered } \\
\text { (except breeders) }\end{array}$ & 699,515 & Production & 75 & $52,463,597$ & $52.4^{6}$ & 0.0 & 52.4 & 2.7 \\
\hline \multirow[t]{3}{*}{ Aquaculture } & All species (domestic) & - & Production & & $835,000,000$ & $477.1^{7}$ & - & $477.1^{7}$ & 398.5 \\
\hline & All species (export) & - & Production & & $\begin{array}{l}2,775,000 \\
000\end{array}$ & $159.1^{8}$ & - & $159.1^{8}$ & 441.4 \\
\hline & All animals & & & & $\begin{array}{l}11,125,535 \\
768\end{array}$ & & & & 2751.4 \\
\hline
\end{tabular}

$A M U$ Antimicrobial use, AGPs Antimicrobial growth promoters (in commercial feed)

${ }^{a}$ Data derived from official country statistics $[10,11]$. 'Census' refers to 'No. standing animals', 'Production' refers to 'No. of slaughtered animals', except for aquaculture, where it refers to 'No. of kg produced'

${ }^{b}$ Excluding antimicrobial growth promoters in commercial feed; ${ }^{1}$ Nguyen et al. (2016) [15]; ${ }^{2}$ Van Cuong et al. (2016) [17]; ${ }^{3,4}$ Average of two studies: Carrique-Mas et al. (2014) [13] and Cuong et al. (2019) [14]; ${ }^{5}$ Based on 50\% of quantities used in chicken production; ${ }^{6}$ Hosoi et al. (2014) [19]; ${ }^{7}$ Pham et al. (2015) [16]; ${ }^{8}$

Assuming that AMU for export production is $1 / 3$ of the magnitude of $A M U$ for domestic production

worse in other LMICs where there are practically no AMU data in any production sector.

Since different animal types are raised over variable periods, the same magnitude of AMU related to body mass may have different implications for the development and maintenance of AMR For example, in Vietnam chickens are raised over a period ranging from 1 to 5 months, compared with 5-8 months for pigs. The implications of this need to be further investigated.

Because of its relative simplicity, we propose to regularly (i.e. annually) estimate/update quantities of antimicrobials used in relation to body mass as a first step to develop a fully-fledged AMU surveillance system. These estimates could be fine-tuned by conducting targeted surveys tailored to different production types (i.e. meat chickens, layers, breeders, fattening pigs, etc.). It may also be necessary to differentiate the extent of AMU by level of intensification of the production system (i.e. backyard, small-scale, large-scale, industrial), as different systems require variable quantities of antimicrobials. It has been shown that in the Mekong Delta of Vietnam smaller chicken farms tend to use more antimicrobials [13]. Lastly, it would be desirable to incorporate detailed information regarding the classes and formulations of antimicrobials used, since there is a great variability 


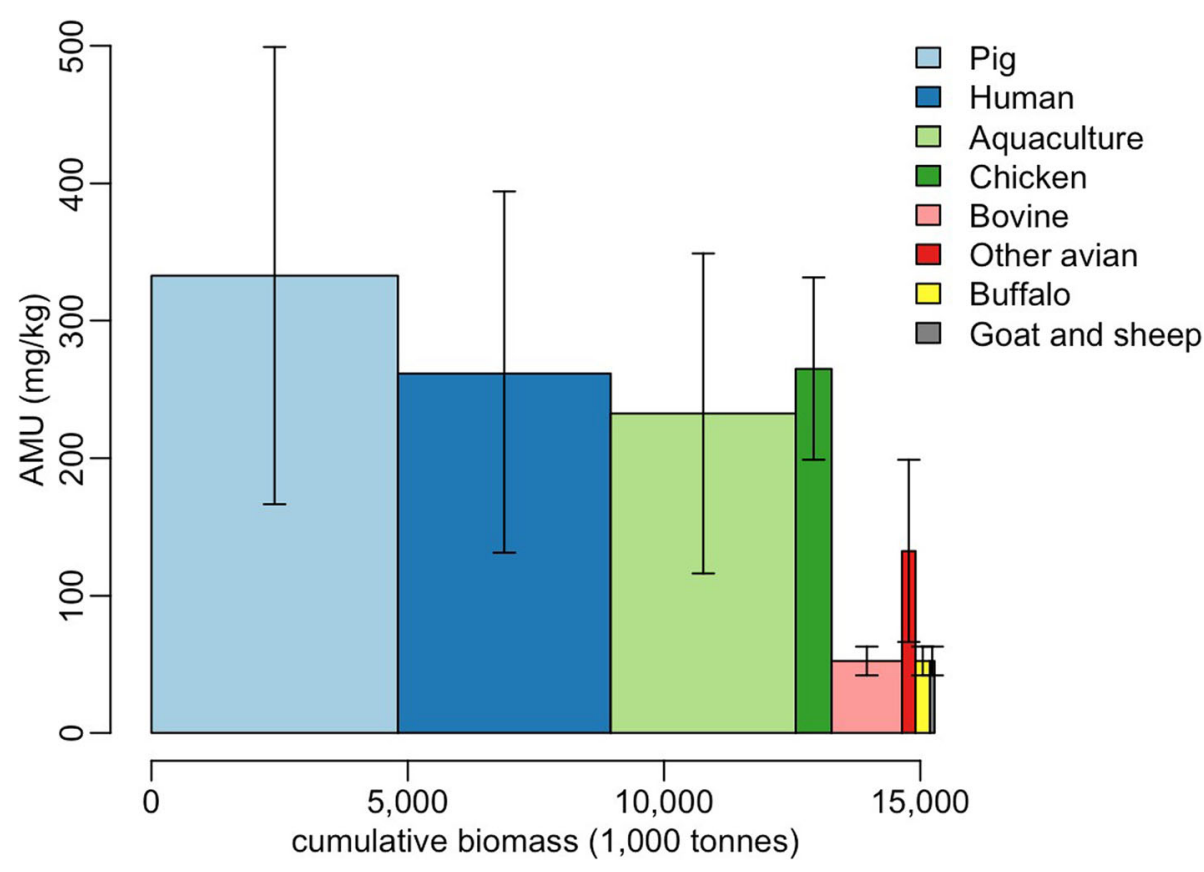

Fig. 1 Two-dimensional diagram representing the estimated annual amounts (areas of bars) of antimicrobials used in each of species (including humans) in Vietnam, and whether these quantities are more affected by the total biomass (width of bars) or the intensity of AMU (height of bars). Bars are sorted from higher to lower overall AMU. AMU = Antimicrobial use. The vertical lines represent the range between best- and worstcase scenarios. 'Other avian' includes ducks, muscovies, geese and quails

regarding the strength of different antimicrobial products and their impact on development of AMR.

In conclusion, in the absence of reliable statistics on sales of AAIs, the challenges of monitoring AMU in animal production in LMICs such as Vietnam can be overcome by the use of innovative approaches that maximize the use of existing animal population statistics and AMU data. These estimates should help elucidate secular changes in AMU and help refine policies and interventions aimed at reducing AMU at country level.

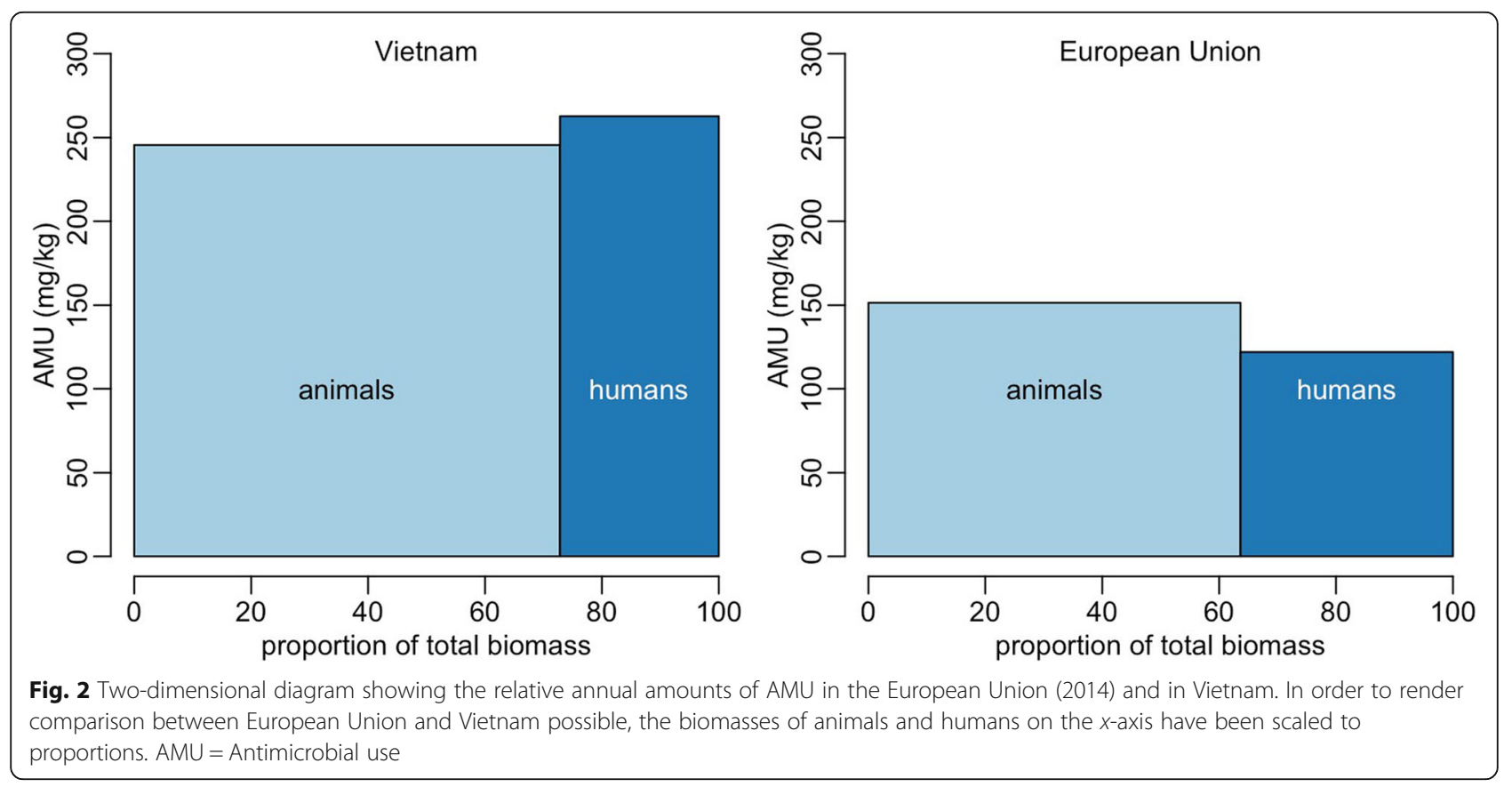




\section{Appendix 1}

\section{Table 2}

Table 2 Estimation of human bodymass of the Vietnamese population from population pyramid, adult bodyweight and age-gender specific bodyweights

\begin{tabular}{|c|c|c|c|c|c|c|c|c|c|c|}
\hline \multirow{2}{*}{$\begin{array}{l}\text { Age } \\
\text { (years) }\end{array}$} & \multicolumn{3}{|c|}{ Total population } & \multicolumn{2}{|c|}{ Average weight (US) (kg) } & \multicolumn{2}{|c|}{ Average weight (Vietnam) ${ }^{a}(\mathrm{~kg})$} & \multicolumn{3}{|c|}{ Estimated bodymass (kg) } \\
\hline & Males & Females & Total & Males & Females & Males & Females & Males & Females & Total \\
\hline$>18$ & $32,448,992$ & $32,448,992$ & $64,897,984$ & & & 58.4 & 50.8 & $1,895,021,133$ & $1,648,408,794$ & $3,543,429,926$ \\
\hline 15 to 18 & $3,582,536$ & $3,390,322$ & $6,972,858$ & 64.4 & 54.4 & 41.4 & 35.4 & $148,234,592$ & $120,066,219$ & $268,300,812$ \\
\hline 10 to 14 & $3,406,698$ & $3,207,976$ & $6,614,674$ & 39.9 & 41.5 & 25.6 & 27.0 & $87,333,258$ & $86,668,284$ & $174,001,542$ \\
\hline 5 to 9 & $3,774,596$ & $3,446,644$ & $7,221,240$ & 22.9 & 22.4 & 14.7 & 14.6 & $55,536,575$ & $50,260,341$ & $105,796,916$ \\
\hline \multirow[t]{2}{*}{0 to 4} & $4,078,564$ & $3,662,281$ & $7,740,845$ & 12.5 & 12.0 & 8.0 & 7.8 & $32,755,967$ & $28,609,739$ & $61,365,706$ \\
\hline & & & $93,447,601$ & & & & & $2,218,881,525$ & $1,934,013,377$ & $4,152,894,902$ \\
\hline
\end{tabular}

${ }^{\mathrm{a}}$ Estimated from US data after applying a correction factor 0.642 (males) and 0.651 (females)

\section{Appendix 2}

Table 3.

Table 3 Estimation of weight of antimicrobial active ingredient from antimicrobials consumed by humans

\begin{tabular}{lllll}
\hline Antimicrobial class & Antimicrobial & $\begin{array}{l}\text { No. DDDs (per } 1000 \text { inhabitants } \\
\text { per day) }\end{array}$ & $\begin{array}{l}\text { Dose in g (for a typical } \\
\text { inhabitant) }\end{array}$ & $\begin{array}{l}\text { Daily amount of AAl (per } 1000 \\
\text { inhabitants) (g) }\end{array}$ \\
\hline Cephalosporin & Ceftriaxone & 8 & 1.5 & 12 \\
$\begin{array}{l}\text { Broad-spectrum beta } \\
\text { lactam }\end{array}$ & Ampicillin & 8 & 1.5 & 12 \\
Macrolide & Azithromycin 8 & 0.5 & 4 \\
Oral fluoroquinolone & Levofloxacin & 8 & 0.5 & 4 \\
All & & & 32 \\
\hline
\end{tabular}

\section{Acknowledgements}

Not applicable.

\section{Authors' contributions}

SB and JC conceived the study and wrote the first draft of manuscript. MC and NC contributed to data analysis and drawing the figures. GT contributed to the discussion. All authors contributed to final version. All authors read and approved the final manuscript.

DDDs Defined Daily Doses, AAl Antimicrobial active ingredient

\section{Funding}

This work was funded by the Wellcome Trust through and Intermediate Clinical Fellowship awarded to Juan J Carrique-Mas (Grant Ref. No. 110085/Z/ 15/Z).

\section{Availability of data and materials}

The data presented and analysed here have all been extracted from publicly available data sets and publications cited in the body text.

\section{Ethics approval and consent to participate}

Not applicable.

\section{Consent for publication}

Not applicable.

\section{Competing interests}

The authors declare that they have no competing interests.

\section{Author details}

${ }^{1}$ Oxford University Clinical Research Unit, Ho Chi Minh City, Vietnam. ${ }^{2}$ Centre for Tropical Medicine and Global Health, Nuffield Department of Clinical Medicine, Oxford University Clinical Research Unit, 764 Vo Van Kiet, Ward 1 District 5, Ho Chi Minh City, Vietnam. ${ }^{3}$ MIVEGEC, IRD, CNRS, University of Montpellier, Montpellier, France. "LMI "Drug Resistance in South-east Asia" (DRISA), Hanoi, Vietnam. ${ }^{5}$ Cambridge Institute of Therapeutic Immunology \& Infectious Disease, Department of Medicine, University of Cambridge, Cambridge, UK.

\section{Received: 20 October 2019 Accepted: 23 December 2019}

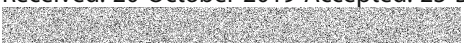

\section{References}

1. O'Neill J. 2014. Antimicrobial resistance: tackling a crisis for the health and wealth of nations. Available at: https://amr-review.org/Publications.html. Accessed 13 Sept 2019.

2. Da Costa PM, Loureiro L, Matos AJF. Transfer of multidrug-resistant bacteria between intermingled ecological niches: the interface between humans, animals and the environment. Int J Environ Res Public Health. 2013. https:// doi.org/10.3390/ijerph10010278.

3. Collignon PJ, McEwen SA. One health - its importance in helping to better control antimicrobial resistance. Trop Med Infect Dis. 2019. https://doi.org/ 10.3390/tropicalmed4010022.

4. World Health Organization. 2015. Global action plan on antimicrobial resistance. Available at: https://www.who.int/antimicrobial-resistance/globalaction-plan/en/. Accessed 29 Sept 2019. 
5. EFSA. ECDC/EFSA/EMA second joint report on the integrated analysis of the consumption of antimicrobial agents and occurrence of antimicrobial resistance in bacteria from humans and food-producing animals. EFSA J. 2017. https://doi.org/10.2903/j.efsa.2017.4872.

6. Anon. OIE annual report on antimicrobial agents intended for use in animals. Paris: International Organisation of Animal Health; 2018. Available at: https://www.oie.int/fileadmin/Home/eng/Media_Center/docs/pdf/ DatabaseFactsheet_EN.pdf. Accessed 28 Sept 2019

7. Anon. 2019. Population pyramid of Vietnam, 2015. Available at: https:// www.populationpyramid.net/viet-nam/2015/. Accessed 20 Sept 2019.

8. Anon. 2019. Average sizes of men and women. Available at: https://www. worlddata.info/average-bodyheight.php. Accessed 20 Sept 2019.

9. Anon. 2019. Weight and height: babies to teenagers. Available at: https:// www.disabled-world.com/calculators-charts/height-weight-teens.php. Accessed 18 Sept 2019

10. Anon. 2018. Animal farming statistics (Vietnam). Available at: http:// channuoivietnam.com. Accessed 9 Sept 2019.

11. Food and Agriculture Organization. 2018. The state of world fisheries and aquaculture. Available at: http://www.fao.org/3/ca0191en/ca0191en.pdf. Accessed 4 Oct 2019.

12. Klein EY, Van Boeckel TP, Martinez EM, Pant S, Gandra S, Levin SA, Goossens $\mathrm{H}$, Laxminarayan R. Global increase and geographic convergence in antibiotic consumption between 2000 and 2015. PNAS. 2018. https://doi. org/10.1073/pnas.1717295115.

13. Carrique-Mas J, Trung NV, Hoa NT, Mai HH, Thanh TT, Campbell J, Wagenaar J, Hardon A, Hieu TQ, Schultsz C. Antimicrobial usage in chicken production in the Mekong delta of Vietnam. Zoonoses Public Health. 2014. https://doi. org/10.1111/zph.12165.

14. Cuong NV, Phu DH, Van NTB, Dinh Truong B, Kiet BT, Hien BV, Thu HTV, Choisy M, Padungtod P, Thwaites G, Carrique-Mas J. High-resolution monitoring of antimicrobial consumption in Vietnamese small-scale chicken farms highlights discrepancies between study metrics. Front Vet Sci. 2019. https://doi.org/10.3389/fvets.2019.00174.

15. Nguyen NT, Nguyen HM, Nguyen CV, Nguyen TV, Nguyen MT, Thai HQ, Ho MH, Thwaites G, Ngo HT, Baker S, Carrique-Mas J. Use of colistin and other critical antimicrobials on pig and chicken farms in southern Vietnam and its association with resistance in commensal Escherichia coli bacteria. Appl Environ Microbiol. 2016. https://doi.org/10.1128/AEM.00337-16.

16. Pham DK, Chu J, Do NT, Brose F, Degand G, Delahaut P, De Pauw E, Douny C, Nguyen KV, Vu TD, Scippo ML, Wertheim HF. Monitoring antibiotic use and residue in freshwater aquaculture for domestic use in Vietnam. Ecohealth. 2015. https://doi.org/10.1007/s10393-014-1006-z.

17. Cuong VN, Nhung NT, Nghia NH, Mai Hoa NT, Trung NV, Thwaites G, Carrique-Mas J. Antimicrobial consumption in medicated feeds in vietnamese pig and poultry production. Ecohealth. 2016. https://doi.org/10. 1007/s10393-016-1130-z.

18. Phu TM, Phuong NT, Scippo ML, Dalsgaard A. Quality of antimicrobial products used in striped catfish (Pangasianodon hypophthalmus) aquaculture in Vietnam. PLoS One. 2015. https://doi.org/10.1371/journal. pone.0124267.

19. Hosoi Y, Asai T, Koike R, Tsuyuki M, Sugiura K. Sales of veterinary antimicrobial agents for therapeutic use in food-producing animal species in Japan between 2005 and 2010. Rev Sci Tech. 2014. https://doi.org/10. 20506/rst.33.3.2337.

20. Anon. Consumption of antimicrobial agents in Thailand in 2017. Thailand: Food and Drug Administration, and International Health Policy Program, Ministry of Public Health; 2019. Available at: https://www.amr-insights.eu/ consumption-of-antimicrobial-agents-in-thailand-in-2017/. Accesed 2 Oct 2019

\section{Publisher's Note}

Springer Nature remains neutral with regard to jurisdictional claims in published maps and institutional affiliations.

Ready to submit your research? Choose BMC and benefit from:

- fast, convenient online submission

- thorough peer review by experienced researchers in your field

- rapid publication on acceptance

- support for research data, including large and complex data types

- gold Open Access which fosters wider collaboration and increased citations

- maximum visibility for your research: over $100 \mathrm{M}$ website views per year

At BMC, research is always in progress.

Learn more biomedcentral.com/submissions 